Mihovil Dabo Sveučilište Jurja Dobrile u Puli, Odjel za humanističke znanosti, Odsjek za povijest I. Matetića Ronjgova 1, HR-52100 Pula

mihovil.dabo@gmail.com

\title{
Stvarni problemi i popularna predodžba: postavljanje Josipa Velikanje za kapelana u Juršićima
}

\author{
Izvorni znanstveni rad | Original scientific paper \\ UDK 27(497.5-3 Istra)"18/19" \\ Primljeno: 14. XI. 2010.
}

\begin{abstract}
Izvadak
Razdoblje Hrvatskoga narodnog preporoda u Istri obiluje značajnim pojedincima. Rezultati što ih je svojim dugogodišnjim trudom postigao biskup Dobrila gdjekad zaklanjaju teškoće na koje je nailazio. Jednako tako, pripovijesti o osebujnom svećeniku Josipu Velikanji neizbježno balansiraju na granici legende i provjerljivih činjenica. Nekoliko sačuvanih dokumenata iz Biskupijskog arhiva Porečko-pulske biskupije pruža korisnu dopunu dosad poznatoj povijesnoj građi o postavljanju "hajdučkog popa" za kapelana u Juršićima. Bolje poznavanje prilika u kojima su, nakon višedesetljetnih nastojanja, izgrađeni crkva i župni stan u Juršićima neizbježno uklanja dio romantične koprene narodne predaje, ali i ukazuje na vrlo realne probleme pri ostvarivanju zamisli o poboljšavanju crkvenih i duhovnih prilika na Roveriji.
\end{abstract}

\section{Sintesi}

Il periodo del Risorgimento popolare croato in Istria è gremito di personaggi di rilevante importanza. I risultati conseguiti grazie all'impegno investito per lungo tempo dal vescovo Dobrila a volte velano le difficoltà cui venne incontro. Allo stesso modo, le vicende narrate sulla figura singolare del prete Josip Velikanje si trovano immancabilmente in bilico tra episodi leggendari e fatti accertabili. Alcuni documenti conservati presso l'Archivio vescovile della diocesi di Parenzo e Pola offrono un supplemento utile al materiale storico finora conosciuto sulla nomina del "prete brigante" a cappellano di Juršići. Una conoscenza approfondita delle circostanze in cui, dopo alcuni decenni di tentativi, sono stati costruiti la chiesa e l'alloggio del parroco a Juršići, dissolve inevitabilmente parte del velo romantico della divulgazione popolare, ma individua anche alcune difficoltà molto 
concrete incontrate in occasione della realizzazione dell'idea del miglioramento delle condizioni ecclesiastiche e spirituali della Roveria.

Ključne riječi: Dobrila, Josip Velikanje, Roverija, kapelanija Juršići, župa Vodnjan Parole chiave: Dobrila, Josip Velikanje, Roveria, curazia di Juršići, parrocchia di Dignano

\section{1.}

Uspomena na Josipa Velikanju (r. 18. ožujka 1843. u Srednjoj Kanomlji, župa Spodnja Idrija, u. 29. listopada 1921. u Idriji), dugogodišnjega kapelana u Juršićima, višekratno je evocirana u historiografskoj i publicističkoj literaturi. Živopisni svećenik koji je svojim duhovničkim radom povezao posljednje desetljeće djelovanja biskupa Jurja Dobrile i prve godine talijanske okupacije Istre po svršetku Prvoga svjetskog rata, ostavio je relativno malo tragova u pisanim izvorima. Osnovne, na izvornom gradivu utemeljene informacije, dosadašnja je literatura uglavnom crpila iz prigodnog članka u Našoj slogi, objavljenog o 25. godišnjici njegova službovanja u Juršićima, ${ }^{1}$ jedanaest pisama biskupa Dobrile upućenih Velikanji, koje je objavio Ernest Radetić $^{2}$ i iscrpnog istraživanja Leopolda Jurce. ${ }^{3}$ Posljednji je autor vlastiti tekst obogatio izvacima iz triju slovenskih publicističkih ili književnih djela, objavljenih u prvoj polovici dvadesetog stoljeća, koja su dio inspiracije pronašla u anegdotama o "hajdučkom popu" Velikanji. ${ }^{4}$ Kasniji opisi roverskih (ne)prilika u drugoj polovici devetnaestog stoljeća često se oslanjaju na nevelik članak Jakova Cecinovića ${ }^{5}$ koji je "iznikao izmed nekadašnjih roverskih hajduka te je svršio gimnaziju i bogosloviju te postao službenik Gospodinov”6 1912., ostavši tako značajnim primjerom uspješnosti Velikanjinog rada.

Velikanjina je biografija leksikografski obrađena u Primorskom biografskom leksikonu, ${ }^{7}$ Slovenskom biografskom leksikonu ${ }^{8}$ i Istarskoj enciklope-

1 “Pop Josip Velikanje župeupravitelj u Juršićih.” (dalje: “Pop Josip Velikanje (NS)”), Naša sloga, br. 83, 22. 10. 1901., 1.

2 Ernest Radetić, "Iz Dobrilina dopisivanja”, Istarski zapisi, Zagreb 1969., 142-147.

3 Leopold Jurca, Josip Velikanje - hajdučki pop, rukopis, Arhiv Istarskog književnog društva "Juraj Dobrila”, osobna arhiva Bože Milanovića, b.o. (Arhivsko gradivo je u postupku sređivanja). Članak je objavljen u, potpisanom autoru nedostupnom, Koledaru Goriške Mohorjeve družbe, Gorica 1976., 156-170.

4 Ivan Pregelj, Božji mejniki, Gorica 1926.; Fran Milčinski, “Gospod Janez in njegovi hajduki”, Humoreske in groteske, Ljubljana 1935., 118-123.; Narte Velikonja, 3 x 88 anekdot, Ljubljana 1943., 85-86. Nav. prema Jurca, Josip Velikanje - hajdučki pop, 15-18.

5 Jakov Cecinović, “Roverija i Dobrila.”, u: Biskup dr. Juraj Dobrila: spomen-knjiga stogodišnjice njegova rodenja, ur. Ante Kalac, Pazin 1912., 303-304.

6 Isto, 304.

7 Lojze Škerl, “Velikanje Josip (Jožef)”, Primorski slovenski biografski leksikon, 16. snopič, Gorica 1990., 171-172.

8 Ljubomir Andrej Lisac, "Velikanje Jožef”, Slovenski biografski leksikon, radna verzija elektronskog izdanja dostupna je na: http://www.sistory.si/biography.html (14. 11. 2010.). 
diji. ${ }^{9}$ K tome, dvije su obljetnice, stotinu godina osnovne škole u Juršićima i osamdeset godina od Velikanjine smrti, inspirirale nekoliko kraćih prikaza njegovog života iz pera Marijana Jelenića, ${ }^{10}$ Miroslava Bertoše ${ }^{11}$ i Stipana Trogrlića. ${ }^{12}$ Konačno, zainteresiranom će čitatelju bez sumnje biti od koristi omanja monografija Cvetka Svetlika. ${ }^{13}$ Ova romansirana Velikanjina biografija, činjenično zasnovana na već navedenoj literaturi, interesantnom je inicijativom, nedugo po izlasku, prevedena na roversku čakavštinu.

\section{2.}

Kako je rečeno, o životu Josipa Velikanje svjedoči razmjerno skromna količina pisanih izvora, ne mnogo opširnija od škrtih i razbacanih svjedočanstava o samoprijegornom dušobrižničkom radu čitavog niza svećenika tijekom duge transformacije istarskog društva pod utjecajem složenih modernizacijskih procesa. Prikazi Velikanjina života stoga su, nužno, spoj šturih podataka iz službenih spisa Porečko-pulske biskupije i šačice anegdota što su usmenom predajom stigle do prvih zapisivača. Iako njegovi mladi dani, skicirani u navedenoj literaturi, vjerojatno zanimljivošću ne zaostaju za zrelim godinama provedenim u raznim istarskim mjestima, izostanak opširnijih izvora utjecao je na brojne nepoznanice iz razdoblja prije ulaska u goričku bogosloviju. Naime, nakon što je 1862. dovršio šesti razred goričke gimnazije, 7. i 8. razred završio je u Senju. Objašnjenje se takvom potezu uobičajeno traži u činjenici što je u Senju bilo moguće u jednoj godini završiti dvije te tako brže dokončati školovanje, a Velikanje je 1862 . već imao 19 godina. ${ }^{14}$

Uslijedilo je najmanje jasno razdoblje Velikanjina života. Naime, svršivši gimnaziju, "proputovav Bosnom dodje u Srbiju, postane slušaocem visoke škole u Biogradu, poprimi se narodnog ustanka”. ${ }^{15}$ Člankopisac Naše sloge koji je ove informacije, za pretpostaviti je, dobio od samoga Velikanje, nije ponudio opširnije objašnjenje ili potpuniji opis istočne avanture mladoga Slovenca, već se zadovoljio lapidarnim zaključkom prema kojemu Velikanje "uvidiv srbsku ekskluzivnost, i osvjedočiv se, da Srbija ne može biti našim

\footnotetext{
9 "Velikanje, Josip”, Istarska enciklopedija, ur. Miroslav Bertoša i Robert Matijašić, Zagreb 2005., 859.

10 Marijan Jelenić, "Hajdučki pop”, Glas Koncila, br. 2 (347), 23. 1. 1977., 8.

11 Miroslav Bertoša, "Duhovnik i narodnjak", Vijenac, novine Matice hrvatske za književnost, umjetnost i znanost, br. 183, 8. 3. 2001., 5.

12 Stipan Trogrlić, “Josip Velikanje - 'hajdučki pop”, Nova Istra, br. 2-3, ljeto-jesen 2001., 223-226.

13 Cvetko Svetlik, Velikan je pop hajduški, Ljubljana 1997. Hrv. prijevod: Hajdučki pop Josip Velikanja, Roverija 2002.

14 Jurca, Josip Velikanje - hajdučki pop, 1; Trogrlić, “Josip Velikanje - 'hajdučki pop”, 223.

15 "Pop Josip Velikanje (NS)", 1.
} 
Piemontom, razočaran vrati se kući." ${ }^{16}$ Školovanje u goričkoj bogosloviji, pod pokroviteljstvom Jurja Dobrile, započeo je 1866., ${ }^{17}$ a uspješno dogotovio u kolovozu 1870. kao bogoslov porečko-pulske biskupije. ${ }^{18}$ Nakon što je sredinom rujna služio mladu misu u Spodnjoj Idriji, već je 6. listopada imenovan kapelanom u župi Bale. Ispomoć pri vjerskim obredima u župnoj crkvi bila mu je dužnošću tek ukoliko bi mu preostalo vremena pored glavnih obaveza: svake je nedjelje i blagdana bio dužan odlaziti u Krmed gdje bi služio misu (namijenjenu i stanovnicima susjednog Golaša), tijekom koje bi, nakon Evanđelja, propovijedao na hrvatskom jeziku, a na hrvatskom bi, prije ili nakon bogoslužja, držao i vjeronauk. ${ }^{19}$

Kad je, već nakon pola godine, imenovan kaptolskim pomoćnikom u pulskoj katedrali, zapale su ga iste dužnosti, odnosno propovijed na hrvatskom jeziku i vjeronauk za hrvatsku djecu. Ubrzano rastuća Pula, međutim, nije bila etnički homogena te je biskupski dekret određivao Velikanju duhovnim pastirom Talijanima jednako kao i Hrvatima. ${ }^{20}$ Ipak, nedostatak klera u Porečko-pulskoj biskupiji, problem koji je biskup Dobrila često isticao u svojim službenim spisima i privatnoj korespondenciji, uzrokom je što se Velikanje u Puli zadržao još kraće nego u Balama: tek dva mjeseca. Novom je biskupskom odlukom, koncem lipnja 1871., postavljen za kapelana u Kavranu, jednoj od dviju kapelanija (druga je bila Marčana) mutvoranske župe. Ionako boležljivi mutvoranski župnik doskora je umirovljen, a Velikanje je postavljen za upravitelja župe. ${ }^{21} \mathrm{U}$ Kavranu se, konačno, zadržao duže vrijeme, odnosno do prelaska u Juršiće.

\section{3.}

Dolazak mladog slovenskog svećenika u kraj naseljen hrvatskim i talijanskim žiteljstvom ne treba čuditi. Kako je istaknuto, biskup Dobrila bio je trajno zabrinut zbog pomanjkanja svećenika, pri čemu valja spomenuti kako je taj problem morio i druge biskupe Austrijske, kasnije Austro-Ugarske Monarhije. ${ }^{22}$ Porečko-pulski biskup se kroz 17 godina svoga službovanja (od 1858.

\footnotetext{
$16 \mathrm{Na}$ ist.mj.

17 Biskupijski arhiv u Poreču (dalje BAP), Urudžbeni zapisnik (dalje UZ), 27. 8. 1866., br. 760.

18 Svetlik, Velikan je pop hajduški, 14.

19 Biskupski ordinarijat Poreč, Čestitom gospodinu Velikanje Josipu, Poreč, 6. listopada 1870., br. 631., nav. prema: Jurca, Josip Velikanje - hajdučki pop, str. 2-3.

20 Isto, 3.

21 Trogrlić, “Josip Velikanje - 'hajdučki pop”, 224.

22 Josip Turčinović, “Juraj Dobrila kao biskup”, u: Istarski preporoditelj Juraj Dobrila 1812 - 1882, ur. Galiano Labinjan, Pazin 1985., 99-100.
} 
do 1875.) višekratno bolno osvjedočio o gubljenju nekadašnjeg utjecaja Crkve na društvo. ${ }^{23} \mathrm{U}$ gradovima i gradićima te su promjene bile uvjetovane prodorom liberalnih strujanja, ali ruralna je unutrašnjost još uvelike živjela ritmom ranog novovjekovlja. ${ }^{24}$ Rođenjem vezan uz istarsko hrvatsko selo, Dobrila je bez sumnje lako uočavao promjene kroz koje je to selo prolazilo. Društvene strukture naslijeđene iz prethodnih stoljeća, tradicionalni duhovni i etički okviri ruralnoga života bivali su najugroženijima upravo u krajevima zakinutim za duhovnu skrb. Sačuvani pisani izvori u bitnom potvrđuju navode Cvjetka Rubetića $^{25}$ o Dobrilinoj brizi za duhovne, ali i materijalne prilike pojedinih župa.

U svojim je nastojanjima Dobrila nužno bio ograničen sredstvima što su mu stajala na raspolaganju. Velikanjin nam primjer ukazuje na neke od taktika kojima je pribjegavao. Koliko je mogao, nastojao je širiti Božju, ali i hrvatsku pisanu riječ raspačavanjem svog molitvenika Otče, budi volja tvoja, prvi put otisnutog 1854. u Trstu; vremešnim je, boležljivim ili prezauzetim župnicima nastojao dodijeliti mlade kapelane kako bi preuzeli dio tereta i udahnuli novu snagu gdjegdje zamrlom vjerskom životu; ako u vlastitoj biskupiji nije mogao pronaći dovoljan broj kandidata za svećenička zvanja, dovodio je duhovnike iz drugih krajeva; konačno, ukoliko je širi prostor, uslijed neprikladnog razgraničenja među župama, odisao moralnom i duhovnom zapuštenošću, nastojao je da se zatečeno stanje izmijeni.

Dobrila nije bio prvi koji je posegnuo za duhovnicima iz Ljubljanske biskupije. U Tršćansko-koparskoj biskupiji već je u vrijeme biskupa Mateja Ravnikara (od 1832. do 1845.) među 336 duhovnika bilo 117 Kranjaca. ${ }^{26}$ Talijanska pisana riječ, u rasponu od žurnalistike do historiografije, kroz dugo je vrijeme, koristeći talijansku verziju spomenutog naziva (Cranzı) prenosila rasprostranjeno uvjerenje kako su međunacionalne trzavice u Austro-ilirskom primorju začete upravo posredovanjem “uvezenog” klera. Višedesetljetno je, nacionalnim antagonizmima motivirano, "zavirivanje” u šematizme Tršćansko-koparske, ali i Porečko-pulske biskupije zabačeno tek u novije vrijeme. ${ }^{27}$

23 Stipan Trogrlić, "Odnos istarskih biskupa prema nacionalnom pitanju i prodoru liberalizma”, Riječki teološki časopis, god. 8., br.1, 2000., 510-513.

24 Miroslav Bertoša, “Istarska 'akulturacijska' ravnoteža druge polovice XIX stoljeća” (dalje: “Istarska 'akulturacijska' ravnoteža”), Etos i etnos zavičaja, Pula - Rijeka 1985., 163-164.

25 Cvjetko Rubetić, Vjekopis Jurja Dobrile, Zagreb 1882., passim.

26 Branko Marušič, “Juraj Dobrila in njegova goriška leta”, u: Istarski preporoditelj Juraj Dobrila, 110.

27 Giampaolo Valdevit, Chiesa e lotte nazionali: il caso di Trieste (1850-1919) (dalje: Chiesa e lotte nazionall), Udine 1979. O kontekstu ove monografije unutar talijanske historiografije: B. Marušič, "Juraj Dobrila in njegova goriška leta", 110.; M. Bertoša, "Istarska 'akulturacijska" ravnoteža", 164-165. 
Kompleksno pitanje brojnosti slavenskoga klera u dvjema biskupijama mora se razmatrati kroz prizmu nejednakog slabljenja interesa za svećenička zvanja u raznim dijelovima Monarhije, ali i unutar jedne pokrajine, kao i nejednakog odnosa spram vjere među pojedinim dijelovima stanovništva. Premreženost religioznih, socijalnih i etničkih čimbenika u temeljnim je crtama dotaknuta (i) u navedenoj literaturi, ali neosporno ostaje nedovoljno obrađenom istraživačkom temom. Ne udaljavajući se suvišno od teme, valja još sažeto navesti nekoliko brojki koje svjedoče o rasprostranjenosti slavenskoga klera u vrijeme Velikanjina dolaska u Juršiće. Istraživači su tako utvrdili kako je u Tršćansko-koparskoj biskupiji oko 80 \% svećenika potjecalo s područja Kranjske i unutrašnje Istre; ${ }^{28}$ 1878. ondje je, od 354 svećenika, 136 potjecalo iz Ljubljanske biskupije; ${ }^{29}$ na koncu, 1875. u Tršćansko-koparskoj i Porečko-pulskoj biskupiji službovalo je ukupno 179 duhovnika iz Ljubljanske i 7 iz Mariborske biskupije te 39 Čeha i Moravljana. ${ }^{30}$

\section{4.}

Roverija je bila prostorom od posebne Dobriline skrbi. Nema sumnje kako naziv potječe od talijanskog naziva za hrast (rovere). Riječ je o kraju između Vodnjana, Barbana i Svetvinčenta, odnosno o više razbacanih sela i zaselaka. Neimenovani člankopisac u Našoj slogi s početka dvadesetog stoljeća opisao je, doduše, njenu zapuštenost, ali prema njemu “još pred tridesetak godina bijahu mnogi krajevi Istre tako zapušteni, da izgledahu kano poludivlji." 1 Već je spomenuto kako je na oslikavanje Roverije sredinom devetnaestog stoljeća veći utjecaj ostvario dramatičan opis Jakova Cecinovića, posebno njegov gotički početak: "Roverija! - Strašna je to riječ, još mnogima u Istri, jer krije u sebi krvavu prošlost, crne priče iz crnijeh dana. Razuzdani Roverac nije poznavao granice između tvoga i moga, nije štedio pravice i poštenja, nego se sasvim bio predao opačini i grijehu." ${ }^{2}$

Romantičarska koprena obojice autora zakriva temeljno ispravno ukazivanje na uzroke nezavidnog položaja Roverije. U vrijeme, za današnje prilike, usporenih komunikacija Roverci su bili prilično udaljeni od većih središta, a područna crkva koja im je bila namijenjena, ona sv. Kirina, bila je smještena

\footnotetext{
28 Valdevit, Chiesa e lotte nazionali, 28.

29 Marušič, “Juraj Dobrila in njegova goriška leta”, 111-112.

30 Jurca, Josip Velikanje-hajdučki pop, 2.

31 “Pop Josip Velikanje (NS)”, 1.

32 Cecinović, "Roverija i Dobrila", 303.
} 
na krajnjem jugu prostrane kapelanije. Zbog toga su, zapravo, bili bez crkve i svećenika, kao i bez škole. K tome, spomenuta je crkva potpadala pod vodnjansku župu kojom su upravljali svećenici talijanske narodnosti, a hrvatski im je jezik najčešće bio nepoznanicom.

Svećenik kojem jezik njegovih župljana nije predstavljao neprelaznu barijeru službovao je sredinom stoljeća sjeverno od Roverije, u župi Svetvinčenat. Riječ je o Antoniju Facchinettiju, koji je svoje simpatije spram hrvatskoga življa ovjekovječio u djelcu O istarskim Slavenima, prvotno objavljenom kao serija članaka u Kandlerovu listu L'Istria tijekom 1847. godine. ${ }^{33} \mathrm{U}$ dopisu biskupu Dobrili sredinom 1860., Facchinetti opisuje otužno stanje u južnom dijelu vlastite župe. Naime, župa Svetvinčenat u to je doba, prema njemu, brojila oko 2400 osoba, od kojih je tek 500 živjelo u središtu, a ostatak u okolnim, raštrkanim selima.

Najudaljenija od župne crkve bila su seoca Režanci, Štokovci, Čabrunići i Boškari, ${ }^{34}$ okupljena u poreznu općinu Štokovci. S obzirom na njihovu udaljenost, ali i brojnost (oko 800 osoba, dakle trećina župe!), ondje su podignute dvije crkve, sv. Germana u Režancima i Blažene Djevice od Sacijana (poznatije kao Blažena Djevica Marija “od trih kunfini”) kraj mjesta Boškari. Naselja su, shodno tome, bila okupljena u kapelaniju sv. Germana kojom je do konca 1851. upravljao vlastiti kapelan, svojedobno jedan od petorice svećenika u župi. Smanjenje prihoda i oskudica klera uzrokom su što je duhovna skrb u čitavoj župi Svetvinčenat, premda se broj stanovnika povećavao, u času kad Facchinetti piše Dobrili povjerena tek dvojici duhovnika: župniku i njegovom pomoćniku. ${ }^{35}$ Vjernicima spomenute kapelanije iz navedenih su razloga čitavo desetljeće bili uskraćeni misa, vjeronauk i, općenito, Božja riječ. Facchinettiju, premda nije bio odgovoran za opisano stanje, župnička savjest nije dala mira zbog pastve povjerene njegovoj skrbi. ${ }^{36}$

Detaljan je uvid u Facchinettijevo pismo bio je potreban, jer se opis prilika u zapuštenoj kapelaniji sv. Germana zasigurno uvelike može primijeniti i na kapelaniju sv. Kirina s kojom je graničila na jugu. Osim toga, očito je kako prostor nedovoljne duhovne skrbi nije obuhvaćao samo prostor vodnjanskog dekanata i župe već se protezao širim područjem, zahvaćajući i južne dijelove

33 Antonio Facchinetti, O istarskim Slavenima, Labin 2005.

34 BAP, Kutija 29 G, kat. I/6, br. 36, 11. 7. 1860., 1. ("Le ville più discoste dal centro e quindi dalla Chiesa parrocchiale sono: Resanzi, Stocouzi, Zabronichi, e Boscari”).

35 Isto, 2. ("Ora per la diminuzione delle rendite, e per la scarsezza del Clero, questa Parrochia, benchè accresciuta di molto in popolazione, non ha che il Parroco ed un Cooperatore.”).

36 Na ist. mj. ("Quantunque questo male da me non dipenda nè in tutto nè in parte, tuttavia non vivo tranquillo sullo stato morale di quelle pecorelle a me affidate".). 
kanfanarskog dekanata, odnosno nezanemariv dio župe Svetvinčenat. Dopis svetvinčenatskog župnika zapravo je pisana analiza akutnog problema što ga je već ranije, vjerojatno tijekom prve Dobriline vizitacije, izložio novom biskupu, željnom poboljšavanja nepovoljnog stanja u kojem se nalazila čitava biskupija.

Tragovi u arhivima zasad nepronađene korespondencije ukazuju kako Dobrila ipak nije bio prvi koji se poduhvatio rješavanja roverskog problema. U sklopu širih demokratizacijskih reformi što su zahvatile Monarhiju po propasti takozvanog Bachovog apsolutizma, koncem 1860. ukinuto je Istarsko okružje, a Istra je, kao markgrofovija (pogranična grofovija) stekla određenu pokrajinsku autonomiju, dok pokrajinskim središtem postaje Poreč. Stoga se, dvadesetak dana po primitku Facchinettijeva pisma, Biskupski ordinarijat obratio pazinskom sudu, skrbniku arhivskog gradiva nedugo prije toga ukinute Okružne vlasti u Pazinu, kako bi mu bio vraćen projekt izgradnje crkve i župnog stana na Roveriji, dostavljen još 15 . veljače 1848. godine. ${ }^{37}$ Koncizna bilješka, naravno, ne omogućava bolje upoznavanje s namjerama Dobrilina prethodnika, biskupa Antona Peteanija (bio je porečko-pulskim biskupom od 1830. do smrti, 1857.), ali ukazuje na višedesetljetne napore uložene u poboljšanje duhovnih prilika na Roveriji. Buduća će istraživanja zasigurno kvalitetnije kontekstualizirati rad čitavog niza biskupa na poboljšavanju vjerskog i materijalnog stanja u Porečko-pulskoj biskupiji od njezina osnutka 1828., rad koji je, među ostalim, doprinio vidljivom prosperitetu Roveraca, čija marljivost početkom dvadesetog stoljeća “upliva na bližnje Barbance, Sanvičenćane i Filipance: a vriedno je spomenuti, da u svem vodnjanskom kotaru obćina roverska imade najmanje duga." ${ }^{38}$ Dobrila se, ipak, i u takvom kontekstu izdvaja jer mu pripada neosporna zasluga što je neumornim radom općenito poboljšao materijalni položaj biskupije, a pojedine je dugotrajne probleme, kao roverski, uklonio ne žaleći vlastita troška ni zalaganja.

Godine 1864. Biskupski je ordinarijat tršćanskom Namjesništvu razložio mizerno stanje stanovništva Roverije uslijed nedostatka svećenika i crkve na prikladnom mjestu. Predloženo je da se crkva i župni stan podignu što prije, a biskup Dobrila izjasnio se spremnim pridonijeti s 2000 forinti. Biskupova je želja bila da se radovi dogotove kroz dvije godine. ${ }^{39}$ Očito je postojala namjera da se opseg roverske kapelanije proširi, jer Carsko i kraljevsko namjesništvo u svom odgovoru traži preciznije podatke o mjestima koja joj se namjerava

37 BAP, UZ, 30. 7. 1861., br. 600.

38 “Pop Josip Velikanje (NS)", 1.

39 BAP, UZ, 18. 5. 1864., br. 492. 
priključiti te o trenutnom broju stanovnika i procjenu njihova broja nakon proširivanja. ${ }^{40}$ Planovi o brzoj izgradnji pokazali su se, kako je poznato, suviše optimističnima jer su crkva i župni stan dovršeni tek u idućem desetljeću, ali ideja o proširenoj kapelaniji ubrzo je prerasla u zamisao o novoj župi. Već 1866. zatražen je pristanak od svetvinčenatskog župnog ureda na odvajanje određenih sela i kuća kako bi bili priključeni budućoj roverskoj župi, ${ }^{41}$ a potvrdni je odgovor stigao početkom iduće godine. ${ }^{42} \mathrm{Na}$ isteku šezdesetih godina planovi su se konačno počeli ostvarivati, jer je C. i kr. namjesništvo, ponovno se informiravši o broju vjernika, ${ }^{43}$ u rujnu 1869 . doista porečkom Ordinarijatu dostavilo na pregled projekt izgradnje nove roverske crkve. ${ }^{44}$ Nakon što je Ordinarijat potvrdio kako projekt odgovara potrebama, proslijeđen je Ministarstvu bogoštovlja. Koncem 1870. Ordinarijat je bio spreman započeti s radovima u Juršićima, jer su državne vlasti odobrile neophodan iznos, ${ }^{45}$ ali situacija se iznova zakomplicirala te je vodnjanski dekan blagoslovio temeljni kamen tek 12. listopada 1873. godine. ${ }^{46}$ Kao što svjedoči natpis nad ulazom, crkva je konačno dovršena 1874., a stanovnici Roverije iduće su godine uputili Franji Josipu I. adresu zahvale. ${ }^{47}$

Izgradnjom crkve nije okončana Dobrilina briga za sređivanje crkvenih prilika na Roveriji. Iako je 29. svibnja 1875., nakon nenadane smrti tršćanskokoparskog biskupa Bartolomeja Legata, imenovan njegovim nasljednikom, ${ }^{48}$ posljednjih je dana svog boravka u Poreču još jednom nastojao pokrenuti osnivanje zasebne župe. U svom dopisu Namjesništvu od 9. srpnja 1875. navodi kako sadašnja kapelanija ima 700 duša, a ako bi joj se, prema već postignutom dogovoru, priključila i četiri najbliža zaseoka svetvinčenatske župe, taj bi se broj popeo na $1052 .{ }^{49}$ Zabrinjavajuće moralno stanje, odnosno zločini koji se s vremena na vrijeme događaju u kapelaniji Juršići i drugim dijelovima Roverije, navode na uporabu svih sredstava kako bi se takve prilike dokončale, a jedno od sredstava svakako je i osnivanje posebne župe. ${ }^{50}$

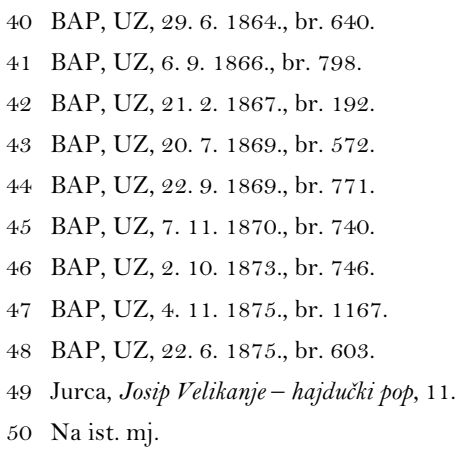


Za razliku od župnog ureda Svetvinčenat koji se sredinom šezdesetih godina složio s odvajanjem dijela župe kako bi se osnovala nova, roverska, ${ }^{51}$ a ta je spremnost potvrđena i sredinom sedamdesetih, ${ }^{52}$ vodnjanski se župni ured nije slagao s inicijativom koja je, Dobrilinim odlaskom, izgubila snažnog i ustrajnog zagovornika. Stoga su Juršići ostali kapelanijom vodnjanske župe još gotovo čitavo stoljeće, a tek su na Badnjak 1950., dekretom biskupa Dragutina Nežića, postali samostalnom župom. ${ }^{53}$ Vodnjanski je otpor dosadašnja literatura, ne bez osnove, povezivala s međunacionalnim trvenjima, sve izraženijim prema kraju devetnaestog stoljeća. ${ }^{54}$ Talijanska želja za suzbijanjem utjecaja već spominjanih Kranjaca i talijanizacijom Hrvatima naseljenih dijelova Istre ipak, barem u početku, nije bila motivom suprotstavljanju Dobrilinim namjerama, jer je tadašnji vodnjanski dekan Pietro Mitton bio naklonjen Velikanji. ${ }^{55}$ Vodnjanski se župni ured, međutim, požalio 1874. porečkom Ordinarijatu kako će ionako neveliki župni prihodi biti dodatno umanjeni odvajanjem roverske kapelanije. ${ }^{56} \mathrm{U}$ kasnijim je desetljećima nacionalni čimbenik vjerojatno ipak odigrao presudnu ulogu, posebno tijekom prve polovice dvadesetog stoljeća.

\section{5.}

Legenda o "hajdučkom popu” začeta je biskupskim dekretom od 15. svibnja 1875. kojim je Velikanje premješten iz Kavrana u Juršiće ${ }^{57}$ Svoju je namjeru Dobrila priopćio Velikanji još mjesec dana prije, ne skrivajući kako "kuća za duhovnika” još nije dovršena, ali kako "Roveriji treba svećenika, koji bi nastojao puk probudit i podbosti, da počme i sam za sebe skrbiti i truditi." 58 U idućih je nekoliko pisama, pisanih hrvatski i njemački, Dobrila izvijestio novoimenovanog roverskog kapelana o svom prelasku na stolicu tršćanskokoparskog biskupa te ga višekratno molio neka, prema njegovim uputama, razborito postupajući dovrši poslove u Juršićima, uključujući i župnički stan koji ga je stajao "mnogo novaca i puno zle volje." ${ }^{59}$ Dobrilina su pisma istovre-

51 Vidjeti bilješku 42.

52 BAP, UZ, 29. 8. 1874., br. 844 i 31. 8. 1874., br. 856.

53 Jelenić, "Hajdučki pop", 8.

54 Svetlik, Velikan je pop hajduški, 33-34.; Trogrlić, “Josip Velikanje - 'hajdučki pop”, 226.; (i posebno) Jurca, Josip Velikanje-hajdučki pop, 11-12.

55 Detaljnije o tome u 6. i 7. dijelu.

56 BAP, UZ, 30. 6. 1874., br. 577.

57 Jurca, Josip Velikanje - hajdučki pop, 3.

58 Pismo J. Dobrile J. Velikanji, 14. 4. 1875., prema: Radetić, “Iz Dobrilina dopisivanja”, 143.

59 Pismo J. Dobrile J. Velikanji, 16. 5. 1875., prema: isto, 144. 
meno hrabrila Velikanju i diskretno ga opominjala neka se, kroz prvo vrijeme, zadovolji radovima koji će župnički stan učiniti useljivim, a kasnije, kad se financijska situacija popravi, kuća će biti dogotovljena. Naime, Dobrilini su troškovi, kako napominje u prvom pismu Velikanji iz Trsta, premašili 10000 forinti i njegova "torbica je sad prazna". ${ }^{60}$

Nakon ovog pisma započinje oduža cezura u komunikaciji tršćanskokoparskoga biskupa i roverskoga kapelana. Iduće sačuvano pismo napisano je u ožujku 1879., a prve Velikanjine godine u Juršićima bile su dosad poznate isključivo kroz predaju što ga je nadživjela, prerastajući u legendu. Pojedine su anegdote ekstenzivno navođene u dosadašnjoj literaturi, čineći od Velikanje sve više književni lik i istodobno zakrivajući spomen na osobu od krvi i mesa. To, naravno, ne znači da je riječ o fikciji. Višedesetljetna prepričavanja neumitno su ponešto nadodala ovim pričama, ali ne treba sumnjati kako im je osnova realna. A ta je osnova - pištolj.

Odmah po dolasku u Juršiće, Velikanje je, navodno, načinio jednostavan "alarmni uređaj", ${ }^{11}$ zavezavši prije spavanja jedan kraj užeta za svoju ruku, a drugi za vola ${ }^{62}$ ili kokoš, ${ }^{63}$ ovisno o pripovjedaču. Kad je noćna aktivnost lokalnih tatova uznemirila životinju, Velikanje se mašio pištolja i dvaput zapucao u zrak, uspješno ih rastjeravši. Sijaset je sličnih ili zanimljivijih priča opisano u dosadašnjoj literaturi o osebujnom svećeniku koji se, kažu, nije odvajao od oružja. Znatiželjni će čitatelj bez previše truda ondje pronaći svjedočanstva o raznolikim sredstvima kojima je zapušteno roversko stanovništvo usmjeravano prema životu bez opačina i lupeštava. Amblematičnom, ipak, ostaje pripovijest o bogoslužju tijekom kojega je jednom rukom podigao križ, a drugom pištolj te zgranutom mnoštvu poručio: “Ako nećete slušati ovo (križ), onda ćete ovo (pištolj)!” ${ }^{64}$

Nameće se zaključak kako je zrelom Velikanji, po dolasku u Juršiće, dobro došlo iskustvo iz negdanje dvojbe u mladenačkim godinama, kad je bio "stendalovski razapet između crvenog (vojne karijere) i crnog (svećeničke službe)” ${ }^{65}$ Ipak, nekoliko dosad nekorištenih dokumenata iz Biskupijskog arhiva u Poreču pomaže u vjernijem prikazu okolnosti u kojima se zatekao.

\footnotetext{
60 Pismo J. Dobrile J. Velikanji, 21. 10. 1875., prema: isto, 146.

61 Isto, 142.

62 Milčinski, “Gospod Janez in njegovi hajduki”, nav. prema: Jurca, Josip Velikanje - hajdučki pop, 17.

63 Svetlik, Velikan je pop hajduški, 27.

64 Jurca, Josip Velikanje - hajdučki pop, 10.; Trogrlić, “Josip Velikanje - 'hajdučki pop”, 225.

65 Bertoša, "Duhovnik i narodnjak", 5.
} 


\section{6.}

Iako literatura tvrdi drugačije, ${ }^{66}$ Velikanje se 6. listopada 1875. nije konačno preselio u Juršiće. Dobrila mu je, doduše, početkom kolovoza savjetovao da se premjesti u Juršiće ili Vodnjan kako bi, lakše nego iz Kavrana, nadzirao radove na župnom stanu, ${ }^{67}$ a vodnjanski je župni ured 4. listopada doista izvijestio Ordinarijat kako će Velikanje preuzeti povjerenu mu kapelaniju tijekom istoga tjedna. ${ }^{68}$ Međutim, iz Ordinarijata je 25. listopada preko vodnjanskog dekana naloženo Velikanji da pođe u dodijeljenu mu kapelaniju, ${ }^{69}$ a ista mu je poruka upućena i 19. studenoga. ${ }^{70}$ Konačno, sredinom prosinca Velikanji je poručeno kako će, ne bude li na svom novom mjestu do Božića, biti suspendiran a divinis za područje čitave dijeceze s izuzetkom Juršića. ${ }^{71}$ Drugim riječima, bilo bi mu zabranjeno dijeljenje sakramenata, uključujući služenje misa i ispovijed.

Poznavanje Velikanjina života do konca 1875., već je spomenuto, temelji se na dekretima porečkog Ordinarijata, Dobrilinim pismima i usmenoj predaji. O njegovim stavovima, odlukama i brigama na ranije opisanim životnim prekretnicama može se tek nagađati. Pretpostavkama, međutim, nema mjesta kad je riječ o prelasku u Juršiće - nevoljni je kapelan svoj očaj i ogorčenje pretočio u pismo vodnjanskom dekanu i kanoniku Mittonu. Odgovarajući na navedena upozorenja i prijetnje sankcijama, od sebe je otklonio svaku krivnju: ona, prema njemu, leži prvenstveno na biskupu Dobrili, a zatim na Rovercima. $^{72}$ Vodnjanskog je svećenika izvijestio kako je tijekom studenoga od tršćansko-koparskog biskupa zatražio 100 forinti kako bi izveo najnužnije radove, bez kojih mu u Juršićima nema opstanka, posebno kroz zimu. Izostanak bilo kakvog odgovora uvjerio ga je kako ga je Dobrila smišljeno prepustio bijednoj sudbini u Juršićima. K tome, izvijestio je porečki Ordinarijat kako će se, čim Dobrila doznači potrebnih 500 forinti za dovršenje radova, premjestiti u Juršiće, ali za izvođenje radova o vlastitom trošku nema ni sredstava ni volje. $^{73} \mathrm{~S}$ druge strane, Velikanje je iznio kako je koncem listopada s rover-

66 Jurca, Josip Velikanje - hajdučki pop, 9.

67 Pismo J. Dobrile J. Velikanji, 3. 8. 1875., prema: Radetić, “Iz Dobrilina dopisivanja”, 144-145.

68 BAP, UZ, 6. 10. 1875., br. 1058.

69 BAP, UZ, 24. 10. 1875., br. 1123.

70 Isto.

71 BAP, UZ, 13. 12. 1875., br. 1374 .

72 BAP, kut. 64J, kat. I/6, 21. 12. 1875., 1. ("È il Vescovo Dobrila sul primo posto e poi i comunisti di Roveria, i quali sono colpa, che io non me ne trovo ora ai Juršići.").

73 Isto, 2. ("Ho scritto anche all' Ordinariato di Parenzo, che quanto prima il Monsignor Vescovo Dobrila consegnerà il detto importo nelle mani di Lei, sul istante me ne porterò ai Juršići; ma eseguire i lavori nella Canonica a spese mie non ho nè mezzi nè volontà."). 
skim općinskim predstavnikom dogovorio prijevoz kolima njegovih stvari iz Kavrana, ali ih je uzalud čekao čitav tjedan. On sam nije imao ni sredstava ni volje izdvojiti 70 ili 90 forinti kako bi se preselio, tim prije što je kroz četiri godine bio kapelanom najsiromašnije kapelanije porečko-pulske dijeceze. ${ }^{74}$

Očito je kako su bure kasne jeseni raspršile utješne Dobriline riječi iz zadnjih pisama, a surova realnost nedovršene župne kuće u zapuštenom kraju suočila je Velikanju s neizvjesnom budućnošću. Odlaskom dotadašnjeg zaštitnika bio je naizgled prepušten vlastitom nagonu za preživljavanje u neprijateljskoj sredini. Biskupovo bodrenje zamijenile su opomene Ordinarijata, a nesigurnost egzistencije poticala je osjećaj izigranosti i samoće. Neugodan ton citiranog pisma odskače od ustaljene predodžbe o beziznimno skladnom radu biskupa Dobrile i njegova pouzdanika, kapelana Velikanje, na duhovnom i materijalnom boljitku dugo zanemarene Roverije, ali istovremeno uklanja suvišnu bajkovitost iz pripovijesti o nimalo bajkovitom vremenu.

Dobrila i Velikanje, obojica na novim dužnostima, suočili su se, dakle, s vrlo realnim problemima, a nastojali su ih prevladati sredstvima što su im stajala na raspolaganju. Dosad poznati izvori o raznorodnim Dobrilinim aktivnostima kojima je nastojao poboljšati položaj hrvatskog stanovništva i istarskog puka općenito, svjedoče kako se biskup nikad nije zanosio nerealnim zamislima. Razumno procjenjujući ostvarivost pojedinih planova, nije se razbacivao neostvarivim obećanjima, zbog čega je za sobom i ostavio čvrste temelje na kojima će nasljednici izgraditi razgranati narodni pokret istarskih Hrvata i Slovenaca. Sve rečeno moguće je primijeniti na njegov odnos prema Roveriji.

Naime, biskupovi savjeti Velikanji neka se strpi nisu bili prazne riječi. Moguće je kako je Dobrila krivo procijenio stupanj nedovršenosti župnog stana u Juršićima, što je i dovelo do kapelanova razočaranja, ali u istom pismu kojim objašnjava svoju trenutnu nemogućnost financiranja dovršetka radova ${ }^{75}$ nagoviješta kako ima "nešto drvi, Bog će dati pa će se prodati, pa ćemo dograditi sve u kući i šternu." ${ }^{76}$ Drva o kojima je riječ zapravo su šume Preseka kod Savičente i Tavernaro, spremne za sječu, zarada od koje je uglavnom pripadala Dobrili kao donedavnom porečko-pulskom biskupu. ${ }^{77}$ Tijekom druge polovice 1876., u korespondenciji porečkog Biskupskog ordinarijata i tršćanskog

\footnotetext{
74 Na ist. mj. ("Ed io non ho nè volonta nè mezzi pecuniari di spendere $70 \mathrm{o} 90$ fior. per la traslocazione da Cavrano ai Juršići, giachè sono Cappellano della più misera Capellania della nostra Diocesi Parentina-Polensi già quattro anni.").

75 Pismo J. Dobrile J. Velikanji, 21. 10. 1875., prema: Radetić, “Iz Dobrilina dopisivanja”, 146.

$76 \mathrm{Na}$ ist. mj.

77 BAP, kut. 42 J, kat. XIV/2, br. 868, Dopis porečkog Ordinarijata tršćanskom Namjesništvu, 14. 8. 1876.
} 
Namjesništva razmatrano je nekoliko načina kojima bi se namirio dug prema Dobrili. Konačno, u listopadu je predložena prodaja jedne državne obveznice, nakon čega bi se tršćansko-koparsko biskupu isplatilo 802,55 forinti, a s ostatkom bi se kupila nova obveznica manje vrijednosti. ${ }^{78}$ Ordinarijat je svoj prijedlog, kojim bi se najbrže i pod najpovoljnijim uvjetima došlo do potrebnih sredstava, motivirao upravo Dobrilinom namjerom da se navedeni iznos upotrijebi za dovršenje župnog stana u Juršićima. Namjesništvo je ovaj prijedlog doskora prihvatilo, ${ }^{79}$ što je Dobriline planove za Roveriju približilo realizaciji.

\section{7.}

Istovremeno, Velikanjina se drama nastavila. Prisiljen preseliti se u Juršiće sredinom $1876 .{ }^{80}$ usprkos neprihvatljivom smještaju, on se u listopadu 1876. obratio porečkom Ordinarijatu. S gorčinom se prisjećao brojnih lijepih Dobrilinih pisama, primljenih godinu ranije, jer mu se činilo kako nakon izdašnih obećanja biskup ne želi više znati za njegove probleme ${ }^{81}$ Kako mu je u lipnju 1876. vodnjanski župnik Mitton prenio obavijest o spomenutom iznosu koji pripada Dobrili, a koji će uskoro biti moguće upotrijebiti za dovršenje radova, Velikanje je prionuo poslu kako bi iskoristio povoljno vrijeme za radove. Izvodeći radove, zadužio se na više strana, a kako novac nije stizao, pojedini su vjerovnici iskazivali namjeru da svoja potraživanja naplate preuzimanjem vlasništva nad župnom kućom. ${ }^{82}$

Najvećim zlom Velikanje smatra to što je u Juršićima potpuno izgubio zdravlje, prvenstveno zbog slabe kvalitete vode, ali i zbog briga. Pismo završava molbom Ordinarijatu da mu se što prije pošalju neophodna sredstva za isplatu dugova i dovršenje radova na cisterni za vodu. Štoviše, otegnu li se radovi na cisterni, moli za otpust iz službe, jer je voda prvi uzrok zdravlju. ${ }^{83}$

Nekoliko dana kasnije, Ordinarijat se obratio vodnjanskom dekanatskom uredu prenoseći Velikanjine probleme. Od dekana Mittona se očekivalo da prenese roverskom kapelanu kako se spomenuta prodaja državne obveznice

\footnotetext{
78 BAP, kut. 42 J, kat. XIV/2, br. 1059, Dopis porečkog Ordinarijata C. i kr. namjesništvu, 8. 10. 1876.

79 BAP, kut. 42 J, kat. XIV/2, br. 1127, Dopis C. i kr. namjesništva, 27. 10. 1876.

80 BAP, kut. 64J, kat. I/6, J. Velikanje biskupskom Ordinarijatu, 11. 10. 1876., 1. ("Scorrerano tosto quatro mesi, dacchè il sottoscritto s'ebbe traslocato ai Juršići in Roveria.").

81 Na ist. mj. ('Il Vescovo Dobrila, il quale nell' autunno e nell' inverno scorso gli prometeva in tante e tante belle lettere ogni necessario soccorso per l'ultimazione dei lavori nella Canonica, ora che sono al luogo non vuol saperne nulla.")

82 Isto, 2. (“....alcuni creditori fanno mostra di procedere al oppignoramento della Canonica, se fra breve tempo non si fa il saldo.")

83 Isto ("Al caso i lavori della Cisterna si prolongassero, il sottoscritto pregherà la demisione, giachè l'acqua è la principal causa della salute".).
} 
ne može provesti kroz nekoliko dana te neka ima strpljenja. Od vodnjanskog se dekanata tražilo da, koliko je moguće, pomogne Velikanji, ukoliko su istiniti navodi o vjerovničkim prijetnjama. ${ }^{84}$ Pismo Mittona Dobrili, pisano sredinom veljače 1877., svjedoči kako je doista kapelanu od vlastitog novca dao u predujam 570 forinti, a motiv je pronašao u velikoj Dobrilinoj brizi za Roverce. ${ }^{85}$

Početkom 1877. Dobrila je konačno došao do navedenih sredstava, a Pietro Mitton poslao mu je početkom ožujka specifikaciju troškova radova na župnoj kući u Roveriji, nakon što mu je Velikanje dostavio podroban račun. ${ }^{86}$ Mitton je povjerio Dobrili kako je Velikanji izrazio svoje nezadovoljstvo što je potrošio šezdesetak forinti preko doznačene 802, na što mu je roverski kapelan odgovorio kako je želio konačno dovršiti župnu kuću te kako preuzima na sebe dio troškova koji je premašio navedenu svotu. ${ }^{87}$

Dan poslije biskup Dobrila uputio je dopis Biskupskom ordinarijatu u Poreču, iz kojeg je razvidno kako je 750,55 forinti namijenio za troškove dovršetka župne zgrade u Juršićima, a preostalih 50 forinti za izradu natpisa koji će biti postavljen nad vratima crkve. ${ }^{8}$ Znatno je važniji drugi dio pisma koji otkriva kako ni Dobrila nije bio zadovoljan razvojem situacije u kapelaniji Juršići po njegovom odlasku s porečko-pulske biskupske stolice. Jednako kao što Mittona drži odgovornim za premašivanje troškova pri dovršetku župne kuće, jer je, navodno, samovoljno dao Velikanji odriješene ruke, ${ }^{89}$ smatra i kako bi ta kuća bila dovršena još prije njegova odlaska iz Poreča da se kapelan pridržavao odredaba onoga tko plaća radove, odnosno Dobrile. Ovime je Dobrila, barem je tako smatrao krajem zime 1877., dokončao svoje staranje za nesretnu i jadnu Roveriju, koja ga je koštala mnogih nezadovoljstava. ${ }^{90}$

Veze biskupa Dobrile s Roverijom ovime se ipak ne prekidaju. Prvo sljedeće svjedočanstvo nanovo uspostavljenih veza je pismo s početka ožujka 1879., dakle poslije pune dvije godine. Izvjesno je kako je komunikacija tršćansko-koparskog biskupa i roverskog kapelana obnovljena prije, a nastavljena je sve do Dobriline smrti. Opsegom nevelika, njihova korespondencija, odnosno četiri Dobrilina pisma u razdoblju od 1879. do 1881., ${ }^{91}$ jasno ukazuje kako je

84 BAP, kut. 64J, kat. I/6, br. 1073, Dopis Ordinarijata vodnjanskom dekanatu, 16. 10. 1876.

85 BAP, kut. 64J, kat. I/6, Pismo P. Mittona J. Dobrili, 17. 2. 1877.

86 BAP, kut. 64J, kat. I/6, 15. 2. 1877.

87 BAP, kut. 64J, kat. I/6, Pismo P. Mittona J. Dobrili, 1. 3. 1877.

88 BAP, kut. 64J, kat. I/6, br. 32, Dopis J. Dobrile porečkom Ordinarijatu, 2. 3. 1877.

89 Isto (“...Signor parroco Mitton credette opportuno di dare carta bianca al cappellano Velikanje senza mettermi a parte di quanto dispore, per cui tocca a lui di pensarvi per le conseguenze.”).

90 Isto ("Con ciò pongo fine alle mie cure per la infelice e misera Roveria, le quali mi costarono tanti dispiaceri.").

91 Radetić, "Iz Dobrilina dopisivanja”, 146-147. 
biskup u Velikanji ipak našao predanog suradnika koji je tijekom desetljećâ neumornog rada u potpunosti ispunio, a možda i premašio Dobrilina očekivanja. Zamišljeni opseg rada ne dopušta prikaz Velikanjinih aktivnosti tijekom gotovo pola stoljeća života u Juršićima. Promatrani u cjelini, plodovi njegove djelatnosti, opisane u navedenoj literaturi, neosporno predstavljaju ostvarenje biskupove želje: "Dao Bog da Vam trud kod toga nevoljnoga puka urodi obilatim plodom!" 92

\section{Zaključak}

Međunacionalne trzavice neuklonjiv su i nezanemariv dio novije istarske povijesti, ali njihov je pretjeran upliv u povjesničarsko rasuđivanje ne jednom doveo do pretjeranog pojednostavljivanja i suviše romantične vizije prošlosti Poluotoka. Jednako kao što proširivanje nacionalne problematike, koja je dugo okupirala historiografiju istarskog devetnaestog stoljeća, društvenim i ekonomskim pitanjima neće zamutiti, već dodatno senzibilizirati povjesničarski pogled na istarsko jučer, povezivanje biskupa Dobile s njegovim prethodnicima i nasljednicima na biskupskim stolicama može samo pomoći u objektivnijem sagledavanju njegova samoprijegorna rada i širokog spektra aktivnosti. K tome, ukazivanje na širok spektar teškoća što su stajale na putu poboljšanju duhovnog i materijalnog položaja hrvatskog naroda u Istri je neophodno želi li se taj proces prikazati što realnije.

Promatrane u dužem vremenskom odsječku, uzglobljene u kontekst što ga pružaju već poznata svjedočanstva o Velikanji i Roveriji, u članku opisane razmirice nisu presudne za oslikavanje odnosa Dobrile i hajdučkog popa, ali pružaju mogućnost boljeg upoznavanja s problemima koji su stajali na putu uključivanju istarskoga hrvatskog puka u modernizacijske procese. Tijekom godina, Velikanjinu su uspješnost potvrđivali rezultati, a nekoć zaostala Roverija pretvorena je u pitom kraj marljivih ljudi. Podizanje škole, osnivanje društva Narodnjak, briga o napretku ratarstva i stočarstva jednako kao i o moralnom napretku povjerene mu pastve ${ }^{93}$ samo su najvidljiviji dokazi dugotrajnog i dubokog Dobrilina nasljeđa.

92 Pismo J. Dobrile J. Velikanji, 3. 3. 1879., prema: isto, 146.

93 Bertoša, "Duhovnik i narodnjak", 5. 


\section{Sažetak}

Članak na temelju nekoliko sačuvanih dokumenata iz arhiva Porečko-pulske biskupije dopunjava dosad poznato povijesno gradivo o postavljanju Josipa Velikanje za kapelana u Juršićima. Rezultati što ih je svojim dugogodišnjim trudom postigao biskup Dobrila gdjekad zaklanjaju teškoće na koje je nailazio. Jednako tako, pripovijesti o osebujnom svećeniku, takozvanom hajdučkom popu, neizbježno balansiraju na granici legende i provjerljivih činjenica. Bolje poznavanje prilika u kojima su, nakon višedesetljetnih nastojanja, izgrađeni crkva i župni stan u Juršićima neizbježno uklanja dio romantične koprene narodne predaje, ali i ukazuje na vrlo realne probleme pri ostvarivanju zamisli o poboljšavanju crkvenih i duhovnih prilika na Roveriji. Uklopljene u širi kontekst, nove činjenice omogućavaju bolje upoznavanje s problemima koji su stajali na putu uključivanju istarskoga hrvatskog puka u modernizacijske procese.

Biskup Dobrila u Velikanji je našao predanog suradnika koji je tijekom desetljećâ neumornog rada u potpunosti ispunio, a možda i premašio njegova očekivanja. Promatrani u cjelini, plodovi njegove djelatnosti neosporno predstavljaju ostvarenje biskupovih želja.

\section{Problemi reali e luoghi comuni: nomina di Josip Velikanje a cappellano di Juršići Mihovil Dabo}

\section{Riassunto}

In base ad alcuni documenti conservati presso l'archivio della diocesi di Parenzo e di Pola, l'articolo aggiunge nuove conoscenze al materiale storico già noto sulla nomina di Josip Velikanje a cappellano di Juršići. I risultati conseguiti grazie all'impegno investito per lungo tempo dal vescovo Dobrila a volte velano le difficoltà cui venne incontro. Allo stesso modo, le vicende narrate sulla figura singolare del cosiddetto prete brigante si trovano immancabilmente in bilico tra episodi leggendari e fatti accertabili.

Una conoscenza approfondita delle circostanze in cui, dopo alcuni decenni di tentativi, sono stati costruiti la chiesa e l'alloggio del parroco a Juršići, dissolve inevitabilmente parte del velo romantico della divulgazione popolare, ma individua anche alcune difficoltà molto concrete incontrate in occasione della realizzazione dell'idea del miglioramento delle condizioni ecclesiastiche e spirituali della Roveria. Inseriti in un contesto più ampio, i nuovi fatti permettono una conoscenza approfondita dei problemi incontrati durante il tentativo di inclusione del popolo istriano croato nei processi di modernizzazione.

Il vescovo Dobrila riconobbe in Velikanje un collaboratore dedicato che nei decenni di instancabile operato rispose interamente alle sue aspettative, forse perfino superandole. Osservati nella loro totalità, i frutti del suo operato rappresentano inconfutabilmente la realizzazione dei desideri del vescovo. 
The real problems and the popular impression: Appointing Josip Velikanje for chaplain in Juršići

Mihovil Dabo

\section{Summary}

Article based on a few surviving documents from the archives of the Diocese of Poreč-Pula complements previously known historical material of placing Josip Velikanje as chaplain in Juršići. Results achieved with effort through the years by Bishop Dobrila sometimes hide the difficulties he was facing. Similarly, stories about the peculiar priest, the so-called "outlaw friar", inevitably balanced on the verge between legend and verifiable facts. Better knowledge of the circumstances in which, after many decades of effort, the church and rectory in Juršići were built, inevitably uncovers the romantic notion of folklore and also points towards the very real problems in the implementation of the idea of improving church and spiritual circumstances of Roveria. Embedded in a broader context, the new facts facilitate better familiarization with problems which stood in the way of including Istrian-Croatian population in modernization process.

Bishop Dobrila found a loyal associate in Velikanje, who during decades of tireless work fully met and perhaps exceeded his expectations. Taken as a whole, the fruits of his activities are the undisputed fulfilments of bishop's wishes. 